JADWIGA JAŹWIERSKA* - LUBLIN

\title{
ZBIORY KARTOGRAFICZNE BIBLIOTEKI UNIWERSYTECKIEJ KUL
}

Zbiory kartograficzne, obejmujące zarówno dzieła zabytkowe, jak i współczesne publikacje, gromadzone były w Bibliotece Uniwersyteckiej KUL od początku jej istnienia, czyli od roku 1918. Początkowo nie miały osobnego inwentarza, ani katalogu, przechowywano je w osobnej szafie w układzie rzeczowym. Pierwsze w zbiorach atlasy i mapy pochodziły z księgozbiorów prywatnych darczyńców Biblioteki, jak hrabiowie Moszyńscy, Franciszek Smolka, Roman Sanguszko, Stanisław Ptaszycki, Mieczysław Popławski. Zbiory powiększały się też drogą zakupów oraz egzemplarza obowiązkowego, który Bibliotece KUL nadsyłano aż do wybuchu drugiej wojny światowej. W roku 1948 powołano osobną Sekcję Zbiorów Graficznych, Kartograficznych i Nut, z której w latach 70 -tych XX wieku wyodrębniona została Sekcja Zbiorów Kartograficznych i Muzycznych. Od roku 2007 zbiory kartograficzne gromadzi się i opracowuje w Sekcji Zbiorów Graficznych, Kartograficznych i Muzycznych w ramach istniejącego Oddziału Zbiorów Specjalnych.

W 1948 roku rozpoczęto systematyczne opracowywanie dokumentów kartograficznych. Filonia Maria Wojtkowska oraz jej następczyni Marii Gonczarow stworzyły używany do dziś krzyżowy katalog kartkowy, z rozbudowanym systemem odsyłaczy, obejmujący hasła autorskie (kartografowie, redaktorzy, autorzy tekstów, sztycharze itd.) i tytułowe, uzupełnione odsyłaczami zagadnieniowymi. Po roku 1952, głównie za sprawą ówczesnego dyrektora Biblioteki, o. Romualda Gustawa OFM, stan posiadania zbiorów kartograficznych wydatnie powiększył się dzięki planowym systematycznym zakupom zarówno dzieł zabytkowych, jak i nowych wydawnictw, a także przez nadsyłany przez Polskie Przedsiębiorstwo Wydawnictw Kartograficznych egzemplarz obowiązkowy. Kilka cennych dzieł przybyło ze Zbiornicy Księgozbiorów Zabezpieczonych, oraz z tzw. depozytu przemyskiego'1. W roku 1997 BU KUL znalazła się wśród bibliotek, którym

* Jadwiga Jaźwierska - mgr historii sztuki, starszy bibliotekarz w Sekcji Zbiorów Graficznych, Kartograficznych i Muzycznych Biblioteki Uniwersyteckiej KUL.

${ }^{1}$ M.Gonczarow, Sekcja Zbiorów Graficznych, Kartograficznych i Nut, ,, Archiwa Biblioteki i Muzea Kościelne”, 23 (1971), s. 164. 
wszystkie krajowe wydawnictwa (w tym także kartograficzne) zobowiązane są nadsyłać egzemplarz obowiązkowy.

W zbiorach kartograficznych BU KUL znajduje się ponad 1300 atlasów, prawie 9000 map (ściennych na wałkach, luźnych arkuszowych i składanych), prawie 3000 przewodników oraz około 300 woluminów wchodzących w skład księgozbioru podręcznego (bibliografie, słowniki, dzieła z zakresu historii i teorii kartografii).

Niniejsze opracowanie ma charakter krótkiego informatora, jest próbą zapoznania przyszłych czytelników z kolekcją zbiorów kartograficznych BU KUL. Dotychczasowe nieliczne artykuły na ten temat były częścią obszerniejszych publikacji zbiorowych, przybliżały głównie historię i działalność Sekcji Zbiorów Kartograficznych oraz skupiały się na najcenniejszych dziełach. Celem autorki jest zaprezentowanie przekroju zasobu zbiorów kartograficznych Biblioteki Uniwersyteckiej KUL, choć i tak nie jest to do końca możliwe ze względu na charakter publikacji i bogactwo dzieł, zasługujących na osobny katalog. Z racji tego, że najcenniejszy trzon kolekcji zbiorów kartograficznych Biblioteki pochodzi z XVIXVIII wieku, tej części poświęcić należy najwięcej uwagi, a tym samym omówienie ich zajmie najwięcej miejsca.

Zbiór najstarszych map i atlasów obejmuje wiele oryginalnych dzieł najznakomitszych europejskich kartografów tworzących od XVI do XVIII wieku, jak Abraham Ortelius, Gerhard Kremer zwany Merkatorem, John Speed, Johann Baptista Homann, Matthäus Seutter, Daniel Friedrich Sotzmann, Robert de Vaugondy, Guillaume Delisle, Giovanni Antoni Bartolomeo Rizzi-Zannoni. Polskich autorów XIX i XX wieku reprezentują m.in. Stanisław Staszic, Joachim Lelewel, Juliusz Kolberg, Franciszek Rodecki, Wojciech Chrzanowski, Eugeniusz Romer. Zbiory kartograficzne BU KUL obejmują też znaczną ilość XIX-wiecznych atlasów niemieckich, francuskich, angielskich i rosyjskich. Wśród nowszych, XXwiecznych publikacji na szczególną uwagę zasługują mapy opracowane przez warszawski Wojskowy Instytut Geograficzny oraz ośrodek lwowski, reprezentowany przez Romera, a wśród współczesnych doskonałe mapy topograficzne wydawane przez Głównego Geodetę Kraju. Oprócz tego Biblioteka dysponuje wieloma współczesnymi mapami i planami miast oraz dużym zbiorem przewodników turystycznych.

\section{Atlasy}

W zasobie Sekcji znajduje się sześć kartograficznych starych druków z XVI wieku, z których najstarszy to najbardziej znana z europejskich kosmografii tamtych czasów, Cosmographia. Beschreibung aller Lendern...autorstwa Sebastiana Münstera. Jest to pierwsza edycja bazylejska z 1544 roku, wydana u Henricha Petri, z 26 kolorowanymi drzeworytami, zawierająca dwie mapy Polski, w tym wzorowaną na zaginionej mapie Bernarda Wapowskiego. Następnymi w kolejności chronologicznej atlasami są Die Karten Deutscher Lander im Brusseller Atlas... (Gottlingen 1573) Christiaana S'Grotena (Sgrootena), geografa Filipa II, 
Civitates Orbis Terrarum (Kolonia ca. 1577) Georga Brauna i Franciscusa Hogenberga, Theatrum Orbis Terrarum (Antwerpia 1584) Abrahama Orteliusa, Descriptionis Ptolemaicae augmentum sive Occidentis notitia... (Louvain 1597) Corneille'a Wytflieta, kolejne wydanie Brauna i Hogenberga Civitates... (Kolonia 1599) oraz Matthiasa Quadusa Geographisch Handtbuch in welchem die Gelegenheit der vornembsten Landschaften des ganzen Erdbodems... (Kolonia 1600).

Wśród najstarszych atlasów w zbiorach znaleźć można liczne przykłady dzieł z tzw. flamandzko-holenderskiej szkoły kartograficznej. Znakomitym jej przedstawicielem był Abraham Ortelius, kartograf, wydawca i kolekcjoner map. Jego Theatrum Orbis Terrarum, owoc współpracy z wieloma znanymi kartografami epoki, jest uważany za pierwszy spójny merytorycznie i wydawniczo zbiór map - najlepszych prac kartograficznych tamtych czasów ${ }^{2}$. Posiadany przez Bibliotekę egzemplarz pochodzi z roku 1584 z oficyny Plantina i zawiera 110 map. Civitates Orbis Terrarum, dzieło Brauna (autor tekstu i wydawca) i Hogenberga (kartografa i rytownika) jest specyficznym atlasem, zawiera bowiem nie tyle mapy, co widoki i plany miast europejskich. Oba egzemplarze należące do Biblioteki są zdekompletowane i z wydanych sześciu tomów obejmują Liber 1 i 2. Autor Geographisch Handtbuch - Quadus, był początkowo sztycharzem, zajmującym się kopiowaniem map, ale podjął się też opracowania własnego atlasu z opisami na odwrocie map $^{3}$. Najbardziej znanym jego dziełem jest również posiadany przez Bibliotekę Fasciculus geographicus... wydany w Kolonii w 1608 roku. Zawiera on m.in. kilka niezwykle cennych miedziorytowych map z obszaru Polski, w tym pierwszą mapę Śląska Martina Helwiga, mapę Polski Wacława Grodeckiego i mapę Księstwa Oświęcimsko-Zatorskiego Stanisława Porębskiego.

Posiadane przez Bibliotekę XVII -wieczne atlasy to przykłady dzieł z najprężniej działających wówczas oficyn europejskich. Szkołę flamandzko-holenderską w zbiorach reprezentuje najwspanialsze dzieło ojca nowożytnej kartografii Gerarda Mercatora - Gerardi Mercatori atlas sive cosmographicae meditationes de fabrica mundi et fabricati figura w wydaniu Hondiusa, zawierające 153 mapy (Amsterdam 1607). Mercator dokonał przewrotu w dziedzinie kartografii, opierając ją na podstawach matematycznych, wprowadził odwzorowanie walcowe, posługujące się siatką przecinających się pod kątem prostym południków i równoleżników, zamiast róży wiatrów. Częściowo poprawił też największy błąd Ptolemeusza polegający na wydłużeniu Morza Śródziemnego. Innymi jego zasługami było wprowadzenie po raz pierwszy terminu ,atlas" dla zbioru razem wydanych map oraz użycie określenia Ameryka dla obu części kontynentu ${ }^{4}$. Drugi egzemplarz atlasu Mercatora datowany na rok 1612, również w wydaniu Hondiusa, zawiera 150 niezwykle ozdobnych kolorowanych map. Ponadto w zbiorach znajdują się jeszcze dwa egzemplarze tzw. Atlasu minor... - edycja francuska z roku 1608 (wydana przez Hondiusa) i łacińska z 1628 (wydana przez Janssoniusa), w których wykorzystano również oryginalne płyty Mercatora. Z kolei wydrukowany w Lon-

${ }^{2}$ K. Szykuła, Zbiory Kartograficzne Biblioteki Uniwersyteckiej we Wroctawiu, Wrocław 1978, s. 28.

${ }^{3}$ Tamże, s. 36.

${ }^{4}$ J. Szaflarski, Zarys kartografii, Warszawa 1955, s. 68-69. 
dynie w roku 1612 Theatrum Imperii Magnae Britaniae... autorstwa Johna Speeda jest przykładem atlasu regionalnego dotyczącego Wielkiej Brytanii. Natomiast obszarom obecnej Belgii i Holandii swoje wydane w roku 1612 Germania Inferior... poświęcił flandryjczyk Petrus Kaerius. Jego rodak Petrus Bertius, kosmograf Ludwika XVIII, jest autorem wydanego w Amsterdamie przez Hondiusa Theatrum Geographiae Veteris z lat 1618-19. Egzemplarz Biblioteki jest współoprawny z Geographia veteris Orteliusa, wydaną w Lejdzie przez Izaaka Elzewira i zawierająca 13 tablic. Kolejne dzieło Orteliusa w zbiorach kartograficznych to wytłoczony przez Plantina w roku 1624 Theatri Orbis Terrarum Pararegon.... Bertius natomiast jest także autorem innego dzieła - Geographia vetus, wydanego w Paryżu w roku 1628. Ciekawą publikacją jest Appendix Theatri Abrahami Ortelii et Atlantis Gerardi Mercatoris continens tabulas geographicas diversarum orbis regionum wydany przez Blaeua w roku $1631 \mathrm{w}$ Amsterdamie.

XVII wiek był czasem działalności wielkich rodzinnych oficyn, prowadzonych przez kilka pokoleń, głównie flamandzkich i holenderskich, jak wydawnictwa Hondiusa i spadkobierców, Officina Blaeviana, czy zakład de Wittów. Nakładem Henricusa Hondiusa (syna wielkiego wydawcy i kartografa - Jodocusa) oraz Joannisa Janssoniusa (zięcia Jodocusa) wyszedł w Amsterdamie po 1631 roku posiadany przez Bibliotekę zdekompletowany Atlas, prawdopodobnie część Nieuwen Atlas. Autorstwa kontunuatorów szkoły flamandzko-holenderskiej - Officina Blaeviana, a konkretnie Guiljelmusa i Johannesa Blaeu, synów Willema Janszoona (korzystającego zarówno z płyt Mercatora, jaki i Orteliusa) jest czwarty tom ( $\mathrm{z}$ dwunastu, które wydano) Theatrum orbis terrarum..., wydany w wersji łacińskiej w Amsterdamie w roku 1645, dotyczy on królestwa Anglii (Regni Angliae). Inny znajdujący się w zbiorach Biblioteki egzemplarz to edycja francuska Le Grand Atlas, Amsterdam 1662, tom piąty - Britannus. Wydawane w większym niż dotąd formacie i bogato iluminowane osiagnęły one wysoki poziom zdobnictwa kartograficznego ${ }^{5}$. Kolejnym wydawnictwem rodzinnym była holenderska oficyna de Wittów (dziadek, ojciec i syn nosili to samo imię Frederik), działająca w 2 połowie XVII wieku w Amsterdamie. Na ten właśnie czas datowany jest posiadany w zbiorach zdefektowany Atlas, zawierający 71 map.

Równolegle ze znakomicie rozwijającymi się wydawnictwami holenderskimi około połowy wieku XVII działała we Frankfurcie oficyna Matthaeusa Meriana starszego. Zainicjował on niespotykane dotąd objętościowo przedsięwzięcie wydawnicze - wychodzącą w latach 1642-1688 Topographię w dziewiętnastu tomach, obejmująca swym zasięgiem kraje Europy Srodkowej. Tekst opracował przedewszystkimMartinZeiler, późniejszeczęści wydalisynowieMeriana ${ }^{6}$. Wzbiorach Biblioteki znajduje się jedenaście tomów, wydanych w latach 1646-1659, są wśród nich m.in.. Topographia Palatinatus Rheni, Archiepiscopatum Moguntinensis, Trevirensis et Coloniensis, Franconiae, Bohemiae, Moraviae et Silesiae, Superioris Saxoniae, Hassiae, Germaniae.

\footnotetext{
${ }^{5}$ R.Grabałowski, Imago Mundi, Wrocław 1972, s. 25.

${ }^{6}$ Szykuła, Zbiory, s. 45.
} 
W drugiej połowie XVII wieku prym w europejskiej kartografii zaczęły wieść oficyny francuskie. Przykładem publikacji z tego obszaru są dwa tomy (pierwszy i trzeci) Atlasu Nouveau Nicolasa Sanson d'Abbeville syna, wydane w Amsterdamie przez Pierre'a Mortiera, na karcie tytułowej, co prawda brak daty, ale mapy są datowane na lata 1692-1696. Innymi ciekawymi obiektami XVII-wiecznymi w zbiorach kartograficznych są Mercurio geografico overo guida geografica in tutte le parti del mondo... cura di Giovanni Giacomo de Rossi... wydany w Rzymie w latach 1684-1714 z 77 miedziorytami oraz pozbawione strony tytułowej i tekstu [Plany miast flamandzkich], zawierające 122 miedzioryty, opatrzone inskrypcją na pierwszej stronie: Relazione delle diecisette Provincie del Paese Basso, a na ostatniej datowane na rok 1672.

Europejskie wydawnictwa XVIII -wieczne reprezentują w zbiorach kartograficznych naszej Biblioteki atlasy znanej oficyny, założonej w Norymberdze przez Johanna Baptistę Homanna, znanej z dbałości nie tylko o masowość nakładów i o doskonałą jakość produkcji ${ }^{7}$. Biblioteka posiada np. Grosser Atlas über die gantze Welt z 1716 roku, Atlas Silesiae z 1750 roku, Atlas novus z 2 połowy XVIII -wieku oraz liczne mapy zawarte w tzw. atlasach sztucznych ${ }^{8}$.

Te ostatnie, szczególnie popularne w XVIII stuleciu, są zawsze dziełami niezwykle cennymi w zbiorach każdej biblioteki ze względu na oryginalnie dobrany przez właściciela-kolekcjonera układ map różnych autorów i różnego pochodzenia, oprawionych wspólnie w jeden klocek introligatorski ${ }^{9}$. W zbiorach Biblioteki znaleźć można siedem takich niezwykłych obiektów. Pierwszy z nich obejmuje 112 map dotyczących świata $\mathrm{z}$ dużą przewagą map krajów europejskich, wydanych w latach 1710-1791 (m. in. J.B. Homanna, T.C. Lottera, P. Schenka). Drugi zawiera 19 map z XVII i XVIII wieku, w większości przedstawiających kraje europejskie, autorstwa J.B. Homanna, J. i T. Danckertsów, F. De Witta i innych. Kolejny atlas sztuczny to zbiór 16 map z XVIII wieku wydanych przez J.B. Homanna i P. Schenka. Następny składa się z 80 map świata z przewagą krajów Europy z lat 1723-1780, autorstwa G. Delisle. Le Brion de la Tour, J.B. Nolina, R. de Vaugondy, G.L. Le Rouge i innych. Kolejny atlas sztuczny z naszych zbiorów to kolekcja 123 przede wszystkim planów i widoków miast z lat 1730-1770, w większości Homanna i sukcesorów. Szósty obejmuje 64 mapy świata i Europy z lat 1718-1800 J.M. Hasiusa, J.B. Homanna i sukcesorów, F. de Witta, H. Jaillota, P. Schenka). Ostatni już atlas sztuczny Biblioteki to kolekcja 40 map głównie z obszaru Europy, z lat 1690-1823, autorstwa T.C. Lottera, H. Jaillota, G. Delisle'a, J.B. Homanna, C. Piqueta.

Inne warte uwagi wydawnictwa XVIII stulecia to atlasy pochodzące z różnych krajów europejskich - jak Johanna Stridbecka Curioses Staats und Kriegs Theatrum...(Augsburg 1710), Nicolasa Gueudeville Atlas historique...(Amsterdam 1714), Johanna Davida Koehlera Descriptio Orbis Antiqui...(Norymberga 1720),

\footnotetext{
${ }^{7}$ M. Sirko, Zarys historii kartografii, Lublin 1999, s. 238.

${ }^{8}$ Atlas sztuczny (A. factice) - jednostka katalogowa (klocek), złożony z map wydawniczo samoistnych, ułożonych dowolnie przez zbieracza i razem oprawionych, za: Encyklopedia wiedzy o ksiażce, red. A. Birkenmajer, Wrocław 1971, s. 82.

${ }^{9}$ Szykuła, Zbiory, s. 58-59.
} 
Rigoberta Bonne Atlas de toutes les parties...(Genewa 1780), Abbe Greneta Atlas portatif... (Paryż 1786), Jeana Denis Barbie du Bocage Recueil de cartes geographiques...(Paryż 1789), Dawida F. Sotzmanna Karte von Polen und angranzes... (Berlin 1793) oraz Franza Johanna Reilly Grosser Deutscher Atlas (Wiedeń 1796).

Interesującym przykładem XVIII -wiecznego atlasu, przeznaczonego dla dzieci jest w zbiorach Atlas dziecinny Dominika Szybińskiego, wydany w 1772 , który oprócz 24 map zawiera kurs geografii w formie pytań i odpowiedzi ${ }^{10}$.

XIX -wieczne atlasy europejskie $\mathrm{w}$ zbiorach Biblioteki to kolekcja najważniejszych publikacji tamtych czasów, stojących na coraz wyższym poziomie, podyktowanym rozwojem badań oraz nowoczesnych technik wydawniczych. Najobszerniej reprezentowane są atlasy wydawców i autorów niemieckich z oficyn w Gotha, Berlinie, Głogowie, Bielefield ${ }^{11}$. Z powodu dużej ilości przykładów ograniczyć się trzeba do wymienienia najbardziej znanych autorów, jak G. D. Reymann (Reymann's topographische Spezialkarte von Schlesien 1845), Justus Perthes (Atlas Antiqus, po 1897), Heinrich Berghaus, autor znakomitego pierwszego kompleksowego atlasu fizyczno-geograficznego (Physikalischer Atlas 1852 oraz Hand-Atlas 1848), Karl Spruner, który opracował szkolny atlas historycznogeograficzny, oparty na najnowszych źródłach naukowych (Hand-atlas 1880, Historisch-geographischer Atlas 1846-1856, oraz Atlas Antiquus, 1865), Adolf Stieler (Hand-Atlas 1823, 1845-1852, 1858 oraz jego pomniejszona wersja SchulAtlas 1826, 1841), Richard Andree (Allgemeiner Hand-Atlas 1881, 1887), oraz J.S. Heinrich Kiepert z weimarskiego instytutu geograficznego (atlasy szkolne i historyczne - Atlas antiquus... 1861, Historischer Schul-Atlas 1861, 1864, 1871, Historisch-geographisch Atlas der Alten Welt 1851).

Na uwage zasługują także dwa dzieła autorstwa Henri de Jomini, szwajcarskiego generała, służącego w armii szwajcarskiej, francuskiej i rosyjskiej, który opracował Atlas portatif pour l'intelligence des relations des dernieres guerres, publiees sans plans: notamment pour la vie de Napoleon... (Paryż 1840) i Atlas portatif pour servir al'explorateur des champs de bataille de Waterloo... (Bruksela 1844). Rosyjskie atlasy XIX -wieczne reprezentują w zbiorach publikacje Nikolaja Pavlisĉeva, Istoriceskij Atlas Rosii z 1873, Igora Zamyslovskiego Ucebnyj atlas po russkoj istorii z 1865 i 1887, Nikolaja Tornau Ucebnyj istoriceskij atlas z 1893. Francuskie publikacje z tego czasu to dzieła takich autorów jak Robert Vaugondy, Antoine P. Hauze, Jean B. Anville oraz A.H. Dufour.

$\mathrm{Z}$ polskich cennych atlasów pierwszym ważnym dziełem jest Giovanniego Antonia Rizzi Zannoniego Carte de la Pologne, w skali 1:690 000. W zbiorach Biblioteki znajdują się trzy egzemplarze Carte..., wydanej w Paryżu w roku 1772, dwa w formie atlasu (w tym jeden zdekompletowany) i edycję na luźnych kartach podklejonych płótnem w introligatorskiej obwolucie. Pracę nad mapą całej Polski za czasów Stanisława Augusta rozpoczął wojewoda Józef Aleksander Jabłonowski, ale nie zdołał ukończyć dzieła, materiały i wskazówki przekazał uczniowi

${ }^{10}$ B. Winiarczyk, Zbiory kartograficzne, w: Zbiory specjalne Biblioteki Uniwersyteckiej Katolickiego Uniwerytetu Lubelskiego, red. M.Trojnacka, Lublin 2004, s. 70.

${ }^{11}$ Sirko, Zarys, s. 245-253. 
Delislea - Zannoniemu. Co prawda nie wykorzystano przy tworzeniu Carte znanych już w Europie pomiarów triangulacyjnych, a rysunek szczegółów był niedopracowany, spełniała jednak ówczesne praktyczne wymagania $i$ jest to pierwsze na tak dużą skalę przedsięwzięcie zainicjowane przez Polaków ${ }^{12}$.

Niezwykle cenne prace kartograficzne prowadził równocześnie pozostający na służbie Stanisława Augusta, Herman Karol de Perhées. Do ostatniego rozbioru zdążył on opracować mapy poszczególnych województw w skali 1:225 000, $\mathrm{z}$ czego kilka posiadamy $\mathrm{w}$ formie fotokopii (Mapa szczegulna województwa poznańskiego, kaliskiego, tęczyckiego, podlaskiego, sandomierskiego, brzeskiego ikujawskiego, mazowieckiego, płockiego i ziemi dobrzyńskiej) ${ }^{13}$.

Biblioteka posiada dwa egzemplarze Atlasu Królestwa Polskiego Juliusza Kolberga, wydane w Warszawie w 1827 roku, jeden w formie luźnych kart na płótnie. Złożony z 8 administracyjnych map województw uzupełniony jest także o dane statystyczne. Inne ważna publikacja z początku XIX wieku to Franciszka Rodeckiego Obraz jeograficzno-statystyczny Królestwa Polskiego z 1810 roku, którego dwa egzemplarze znajdują się w zbiorach. Zawiera on, co prawda tylko 1 mapę administracyjna, ale oprócz tego posiada obszerne tablice statystyczne $\mathrm{z}$ dużą ilością informacji.

Pierwsza połowa XIX wieku to także okres działalności znakomitego polskiego uczonego Joachima Lelewela. Z jego licznej spuścizny w zbiorach Biblioteki znajduje się pięć tytułów, m.in. dwa egzemplarze opracowanego na użytek szkół Atlasu do historyi i geografii starożytney (Warszawa 1828). Géographie du moyen âge - ilustrowana mapami historia kartografii światowej, wydana w Brukseli w 1850 roku jest niestety niekompletna, zawiera 15 map. W zbiorach znajduje się także Album rytownika polskiego, wydany w Poznaniu w 1854 roku z 42 tablicami, a także Histoire de Pologne... Atlas contenant les tableaux chronologiques, et les cartes geographiques... (Paryż 1844), poszerzona wersja emigracyjna Atlasu do dziejów Polski ${ }^{14}$.

Dotychczasowe osiagnięcia kartograficzne zostały przyćmione przez dzieło Kwatermistrzostwa Polskiego - wydaną w 1843 r. (z datą 1839) Karte topograficznq Królestwa Polskiego, w skali 1:126000. Mapy o wyjątkowej czytelności, bogatej treści i stosunkowo dużej dokładności, mimo iż nie oparte w pełni na pomiarach triangulacyjnych, odznaczały się wysokim poziomem wykonania ${ }^{15}$. Występują one w zbiorach kartograficznych Biblioteki KUL w postaci fotokopii.

Następny w kolejności chronologicznej niezwykle ważny atlas dotyczący Polski to Karta dawnej Polski z przylegtymi okolicami krajów sqsiednich generała Wojciecha Chrzanowskiego, wydana w Paryżu w 1859 roku w skali 1:300 000. Opracowywana była z myślą o przyszłym powstaniu narodowym, a pracowali nad

${ }^{12}$ Centralny Katalog Zbiorów Kartograficznych. Wieloarkuszowe mapy topograficzne ziem polskich 1576-1870, red. T. Paćko, W. Trzebiński, Wrocław-Łódź 1983, s. 12.

${ }^{13}$ Tamże, s. 22-23.

${ }^{14}$ Z. Rzepa, Kartografia historyczna Joachima Lelewela, „Ze skarbca kultury”, 34 (1980), s. 45 .

${ }^{15}$ W'́ród starych map i atlasów Biblioteki Narodowej w Warszawie, red. B.Krassowski, Warszawa 1982, s. 19. 
nią także inni oficerowie Kwatermistrzostwa, później zaś pracownicy Biblioteki Polskiej w Paryżu ${ }^{16}$. Efektem ich starań jest imponujący wielkością, złożony z 48 map atlas. Zarzuca mu się co prawda niezbyt dokładne odwzorowywanie rzeźby i nieścisłości w lokalizacji niektórych punktów terenu, ale całość jest uznawana za jedno z największych osiągnięć kartografii polskiej XIX wieku. Z map Chrzanowskiego korzystał Aleksander Jabłonowski, twórca posiadanej przez Bibliotekę KUL drugiej (jedynej wydanej zresztą) części Atlasu Historycznego Rzeczypospolitej, noszącej tytuł Ziemie Ruskie Rzeczypospolitej, która wyszła w latach 18991904 i obejmowała przedział czasowy XVII-XVIII wieku

Z innych wydawnictw XIX -wiecznych można wspomnieć też Atlas do dziejów Polski Eligiusza Niewiadomskiego, którego trzy egzemplarze z roku pierwsze wydanie z roku 1899, oraz dwa kolejne z 1907 i 1920 znajdują sie w zbiorach. Ich autora pamięta się chyba dziś bardziej jako zabójcę prezydenta Narutowi$\mathrm{cza}^{17}$.

Niezwykłymi, jeśli chodzi o jakość i dokładność kartograficzną atlasami są dzieła wielkiego polskiego kartografa Eugeniusza Romera, twórcy polskiej szkoły kartograficznej, założyciela lwowskiej Książnicy-Atlas. Jego Geograficznostatystyczny atlas Polski wydany w Warszawie w 1916 roku został opracowany na potrzeby konferencji pokojowej, która miała zadecydować o przyszłych granicach II Rzeczypospolitej. Biblioteka posiada trzy egzemplarze pierwszego wydania i jeden z 1921 roku. Polski atlas kongresowy z 1921 z kolei zawiera wybór map przygotowanych przez Biuro Geograficzne Delegacji Polskiej w Paryżu podczas obrad konferencji pokojowej w 1919 roku. Następnym z atlasów Romera jest Powszechny atlas geograficzny (Lwów 1934), w którym także zastosowano charakterystyczne cechy jego kartografii, jak przedstawianie rzeźby terenu metodą hipsometryczna, stałe barwy dla konkretnych warstw hipsometrycznych i znaczną generalizację rysunku ${ }^{18}$.

Z okresu międzywojennego pochodzą m.in. posiadane przez Bibliotekę KUL Atlas jezior tatrzańskich Ludomira Sawickiego, Ignacego Paderewskiego Maps Representing Western Frontiers of Poland (1933), a także jedne z pierwszych polskich atlasów samochodowych, jak Polski atlas samochodowy (Warszawa 1938) i Atlas Polski „Continental” dla automobilistów (Warszawa przed 1939). Z licznych publikacji powojennych na szczególną uwagę zasługuje kilka wydań Atlasu Świata Służby Topograficznej Wojska Polskiego, wydanym przez PWN, z lat 1962-1968, będącego niezwykle udaną próbą opracowania wielkiego atlasu ogólnogeograficznego świata. W zbiorach kartograficznych znajduje się także wiele innych współcześnie wydawanych atlasów, zarówno ogólnogeograficznych, jak i tematycznych (np. historyczne, biblijne). Obecnie, dzięki prawu do egzemplarza obowiązkowego Biblioteka KUL otrzymuje niemal wszystkie najważniejsze polskie produkcje kartograficzne.

${ }^{16}$ Sirko, Zarys, s. 281.

${ }_{17}$ A. Piber, Eligiusz Niewiadomski, w: Polski Stownik Biograficzny, t. 23, Wrocław 1978, s. 74.

${ }^{18}$ Eugeniusz Romer, geograf i kartograf trzech epok. Katalog wystawy, Warszawa 2004, s. $15-19$. 


\section{Mapy}

Najstarsze mapy luźne w zbiorach są niekiedy częściami atlasów, tak jest w przypadku widoku Lublina, datowanego po 1572 roku, który pochodzi ze wspomnianego wcześniej Civitates Orbis Terrarum Brauna i Hogenberga, a także A newe mape of Poland, ok. $1626 \mathrm{z}$ atlasu Speeda. Całość obszaru Polski przedstawia kilka XVII i XVIII -wiecznych wydań map luźnych. Należą do nich Etats de la couronne de Pologne H. Jaillota z roku 1696, Auctior et correctior tabula chorographica Regni Poloniae Ericha J. Dahlberga z 1697 roku, Mappa Geographica regni Poloniae Tobiasa Meyera z 1757, Mappa geographica... Regnum Poloniae et Magnum Ducatum Lithuaniae Tobiasa Lottera z 1772, Polonia... spadkobierców Homanna z 1772 r., Carte generale et itineraire de la Pologne I. van Jagen 1781.

Unikatową mapą, będącą własnością Biblioteki KUL jest czteroczęściowy Plan kopalni i miasta Wieliczki autorstwa geometry Marcina Germana, wydany w Gdańsku 1645 roku. Jest to najstarszy w Polsce, a jednocześnie jeden z pierwszych w Europie planów górniczych, do których zostały wykorzystane pomiary geodezyjne ${ }^{19}$. Plan miasta oraz trzy plany żup solnych zostały wykonane i wydane przez sztycharza Wilhelma Hondiusa, uzupełnione są realistycznymi scenami przedstawiającymi pracę w kopalni i odznaczają się niezwykłą szczegółowością i precyzją rysunku ${ }^{20}$.

Następnym rarytasem jest przechowywana w zbiorach rękopiśmienna Mappa dioeceseos Chelmensis et Belzensis... ritus graeco-catholici... z roku 1782. Wykonana została na zlecenie unickiego biskupa Maksymiliana Ryłły przez anonimowego kreślarza na podkładzie mapy Galicji i Lodomerii Josepha Liesganiga. Prezentuje granice i podziały administracji państwowej i świeckiej na terenie diecezji chełmskiej $^{21}$

Poza wymienionymi ostatnio niewątpliwymi unikatami kolekcja map zbiorów kartograficznych zawiera sporo luźnych map różnych regionów Polski, jak np. Pomorza, Prus, Śląska Homanna i spadkobierców, H. Müllera, T. Maiera, N. Sanson d'Abbeville'a.

W zbiorze map poświęconych Litwie wyróżnia się tzw. mapa Radziwiłła Sierotki, czyli Magni Ducatus Lithuaniae opracowana na zlecenie i ze środków księcia Mikołaja Krzysztofa Radziwiłła przez Tomasza Makowskiego w 1613 roku. Stanowi pierwsze oryginalne opracowanie kartograficzne ziem Wielkiego Księstwa Litewskiego, zawiera ponad 500 miejscowości z terenów Litwy, Wołynia, Podlasia, przygranicznych terenów Ukrainy, Rusi Czerwonej, Mazowsza i Małopolski $^{22}$. Egzemplarz Biblioteki jest przeskalowanym wydawnictwem z 1650 ro-

${ }^{19}$ Nad złoto droższe. Skarby Biblioteki Narodowej, red. H. Tchórzewska-Kabata, Warszawa 2000, s. 128.

${ }^{20}$ Winiarczyk, Zbiory, s. 69-70.

${ }^{21}$ B. Szady, Mapa unickiej diecezji chetmskiej z 1782 roku jako przykład kartografii wyznaniowej, rękopis udostępniony przez autora będzie wydany w materiałach z XXII Ogólnopolskiej Konferencji Historyków Kartografii.

${ }^{22} \mathrm{~K}$. Buczek, Dzieje kartografii polskiej XV-XVIII wieku. Zarys analityczno-syntetyczny, Wroclaw 1963, s. 51. 
ku, posiada on uzupełnienie w postaci mapy biegu Dniepru od Czerkas do ujścia. Inne mapy tych terenów w zbiorach to Magni Ducatus Lituaniae de Witta (1760), Lithuania Mercatora (XVII wiek), Charte von Russisch Litauen wydana przez Homann Erben (1775), Typus generalis Ukrainae z oficyny Janssoniusa i M. Pitta, przeróbka mapy Ukrainy Beauplana 1690.

Wśród luźnych map Europy wyróżniają się np. mapy morskie, jak Nova Maris Caspii z 1735 roku, czy Thomasa Jefferysa A chart of the British Channel z roku 1775. Inne liczne XVIII -wieczne mapy Europy w zbiorach to egzemplarze opracowane przez wymienianych już G. Blaeu, J. Danckertsa, M. Lottera oraz J. Homanna.

Niezwykle ciekawym zabytkiem polskiej kartografii XIX -wiecznej jest egzemplarz składającej się z czterech arkuszy Carta geologica totius Poloniae, Moldaviae, Transylvaniae, et partis Hungariae et Valachiae, opracowanej przez Stanisława Staszica w latach 1806-1810, a opublikowanej w 1815 r. Jest to pierwsza na taką skalę mapa geologiczna Polski i krajów sąsiednich, będącą pionierskim opracowaniem w tej dziedzinie wiedzy. ${ }^{23}$ Prezentuje dokładnie opracowaną sieć hydrograficzną i uwzględnia rzeźbę terenu.

W zbiorze map XIX -wiecznych wyróżniają się zwłaszcza mapy topograficzne wydawane przez wojskowe służby trzech zaborców. Biblioteka posiada np. 13 arkuszy popularnej trzywiorstówki, czyli rosyjskiej Voennno-topograficeskej karty Evropejskoj Rosii w skali 1: 126000 (Petersburg 1876-1915). Są to mapy jednokolorowe, o rzeźbie terenu przedstawionej metodą kreskową, obejmujące głównie gubernie suwalską, grodzieńską, łomżyńska, warszawska, siedlecką, kaliska, lubelską, wołyńską. Innym przykładem są posiadane przez Bibliotekę 32 sekcje Map sztabowych austriackich, wydawanych w Wiedniu w latach 1894-1916 w skali 1:75000. Dla obszaru Galicji pomiary przeprowadzali geodeci K. u. K. Militärgeographisches Institut, wśród których nie brakowało Polaków. Innym przykładem mapy topograficznej jest 13 arkuszy General Karte von Mitteleuropa w skali 1:200 000 (Wiedeń 1901-1918) oraz 22 sekcje Karte des westlichen Russland 1:100 000 (Berlin 1915), będące pomniejszeniem rosyjskiej Nowej Topograficzeskej Karty Zapadnoj Rossji, używanej podczas I wojny światowej zarówno przez Rosjan, jak i Niemców. Wojenne potrzeby często sprawiały, że wszystkie strony konfliktu podkradały sobie mapy i publikowały je dla swoich potrzeb z niezbędnymi zmianami.

Odzyskanie przez Polskę niepodległości postawiło przed wojskowymi służbami nie lada wyzwanie - opracowanie aktualnych map nowego państwa. Było to zadanie niezwykle trudne, ponieważ po zaborcach młode państwo odziedziczyło kilka układów triangulacyjnych z ośmioma różnymi punktami odniesienia. Zadania opracowania map nowo powstałego państwa polskiego, miał dokonać powołany w 1919 roku Wojskowy Instytut Geograficzny, który w krótkim czasie zdołał dorównać europejskim wydawcom. Na początku aktualizowano mapy zaborców, będące podstawą map w skali 1:100 000, wydawanych do 1926 roku. Po sporządzeniu własnej sieci triangulacyjnej zaczęto wydawać oryginalne arkusze map,

${ }^{23}$ B. Olszewicz, Kartografia polska XIX wieku, t. 1, Warszawa 1998, s. 44. 
znanych jako Mapy sztabowe taktyczne 1:100 000. Zbiory kartograficzne zawierają dwa niemal kompletne (brakuje kilku sekcji) zestawy tych map, wydawanych w latach 1924-1938. Znajdują się wśród nich przykłady zarówno typu drugiego (znaki czarne, warstwice brązowe), trzeciego (dwu i czterobarwne) oraz tzw. normalnego (czterobarwne). Oparte na opracowanym przez Polaków tzw. odwzorowaniu quasi-stereograficznym WIG, drukowane we własnej szacie graficznej na specjalnie opracowanym papierze, nie miały sobie równych w Europie i uznawane były za majstersztyk sztuki kartograficznej ${ }^{24}$. Ponadto Biblioteka posiada także 76 sekcji Map sztabowych operacyjnych 1:300 000, wydawanych w latach 19241937, oraz 54 arkusze Mapy topograficznej 1:25 000 (1933-1939). Po przegranej przez Polskę kampanii wrześniowej 1939 roku, kilku oficerów WIG podjęło prace na rzecz niemieckiego okupanta. Drukowali wówczas kontrreprodukcje map WIG na potrzeby Wehrmachtu, który posługiwał się nimi na terenie okupowanej Polski i podczas ataku na Związek Radziecki. W zbiorach kartograficznych znajduje się także wersja map WIG 1:100 $000 \mathrm{w}$ wersji niemieckiej (620 arkuszy).

Powojenne mapy w zbiorach to przede wszystkim duża liczba map ogólnogeograficznych, oraz specjalnych (np. historycznych, wyznaniowych, komunikacyjnych), zarówno świata, jak i Polski, oraz liczne plany miast. Znaczny rozwój ruchu turystycznego $\mathrm{w}$ ostatnich latach zaowocował wprost niezwykłą ilością map i planów wydawanych właśnie na użytek turystów.

\section{Przewodniki}

Przewodniki były gromadzone w zbiorach od początku powstania Sekcji Zbiorów Kartograficznych aż do lata 2007 r. Najnowsze wydania trafiają już do magazynu i udostępnia je Czytelnia Główna. W Zbiorach Kartograficznych uzupełnia się jedynie na bieżąco serie oraz gromadzi przewodniki dotyczące dawnych ziem polskich, lubliniana, oraz wydania sprzed 1950 roku.

Największą grupę stanowią przewodniki turystyczne, wydawane od lat międzywojennych, przez wydawnictwa z lat 50 -tych i 60 -tych XX wieku, będących niekiedy już tylko świadectwem tamtych czasów, aż po współczesne, ilustrowane serie National Geografic, Pascala, Berlitza, Bezdroży itp. Są one doskonałym źródłem wiedzy choćby dla studentów historii sztuki, przygotowujących się do objazdów naukowych, a także dla czytelników planujących bliższe i dalsze podróże.

Oprócz przewodników turystycznych gromadzono w zbiorach kartograficznych przewodniki po cmentarzach, zarówno tych znanych, jak wileńska Rossa, Cmentarz Łyczakowski we Lwowie, Powązki warszawskie, czy Cmentarz Rakowicki w Krakowie, jak i po cmentarzach małych miast i wsi, także za granicami Polski.

Wydzielony jest zbiór przewodników wydawanych w latach międzywojennych, dotyczących Europy, a także dawnych ziem polskich - tzw. dawnych Kresów II Rzeczpospolitej - Wołynia, Ukrainy, Litwy, zawierający również reprinty

\footnotetext{
${ }^{24}$ Wśród starych atlasów, s. 21.
} 
dawnych wydań. Najstarsze w tej grupie są: Przewodnik po Lwowie wydany przy wspótudziale Wydziału gospodarczego V zjazdu Lekarzy i Przyrodników polskich (Lwów 1888), Wacława Ciechowskiego Kijów i jego pamiatki (Kijów 1901) oraz Powiat mohylowski w guberni podolskiej. Opis geograficzno-historyczny wszystkich miast, miasteczek, wsi, przysiotków, futorów... (Kraków 1902) autorstwa Władysława Górskiego. Znaleźć można tu zarówno przewodniki obejmujące większe obszary, jak Nowogródczyzna, Polesie, województwa stanisławowskie, tarnopolskie, ziemię wileńska, Wołyń, oraz przewodniki po poszczególnych miastach kresowych. Reprezentowane są m.in.: Lwów (Lwów. Przewodnik orjentacyjny z roku 1930, Aleksandra Medyńskiego Lwów. Ilustrowany przewodnik dla zwiedzajacych miasto z roku 1937), Wilno (Juliusza Kłosa Wilno. Przewodnik krajoznawczy, Wilno 1929, Mariana Morelowskiego Zarysy sztuki wileńskiej z przewodnikiem..., Wilno 1939, z autografem autora), Drohobycz, Druskienniki, Grodno, Kamieniec Podolski, Łuck, Sambor. Zbiory zawierają także kilka przewodników po regionach Polski autorstwa znakomitego geografa Mieczysława Orłowicza, jak Przewodnik po ziemiach dawnej Polski, Litwy i Rusi (Warszawa 1914), Ilustrowany przewodnik po Galicyi, Bukowinie, Spiżu, Orawie i Ślasku Cieszyńskim (Lwów 1919), Ilustrowany przewodnika po Wschodnich Karpatach, Galicyi, Bukowinie i Węgrach (Lwów 1914), Ilustrowany przewodnik po Wołyniu (Łuck 1929) oraz trzy egzemplarze Przewodnika po Polsce w 4 tomach pod red. Stanisława Lenartowicza (Warszawa 1935-1937).

\section{Księgozbiór podręczny}

Księgozbiór podręczny gromadzi podstawowe publikacje stanowiące warsztat pomocniczy służący do opracowania dokumentów kartograficznych Oprócz bibliografii, drukowanych katalogów zbiorów kartograficznych krajowych i zagranicznych, słowników geograficznych i leksykonów, zawiera np. wiele ciekawych pozycji z zakresu kartografii i jej historii.

Jeśli chodzi o pozycje bibliograficzne z zakresu kartografii, najstarszymi w zbiorach są Mappografia dawnej Polski Edwarda Rastawieckiego z roku 1846 oraz Katalog atlasów Biblioteki Uniwersytetu Stefana Batorego w Wilnie... (Wilno 1940) Mikołaja Franciszka Dzikowskiego, ofiarowany Bibliotece przez prof. Mariana Morelowskiego, z własnoręczną jego adnotacją o wyjątkowej wartości tego dzieła. Oprócz tego posiadamy publikacje autorstwa nestora polskiej historii kartografii, Bolesława Olszewicza, jak bibliofilskie, numerowane wydanie Polskich zbiorów kartograficznych (Warszawa 1926), Zbiory kartograficzne, Próba instrukcji do katalogowania... (Warszawa 1915), Polska kartografia wojskowa (Warszawa 1921), Kartografie polska: przeglad chronologiczno-bibljograficzny 3 części (Lwów 1930-1932). Nie może zabraknąć również Centralnego Katalogu Zbiorów Kartograficznych pod redakcją Mariana Łodyńskiego, wydawanego w latach 1961-2000.

Niektóre ze słowników w księgozbiorze to: Johanna Georga Theodora Graesse Orbis Latinus oder Verzeichniss... (Drezno 1861), Johanna Georga Theodora 
Graesse, Friedricha Benedicta, Helmuta Plechl Orbis Latinus. Lexikon lateinischer geographischer Namen... Bd.1-3 (Brunszwik 1972), Stownik nazw miejscowych Europy Środkowej $i$ Wschodniej XIX $i$ XX wieku Henryka Batowskiego (Warszawa 1964), Stefana Kotarskiego Stownik zlatynizowanych nazw miejscowych (Warszawa 1955).

Historia kartografii reprezentowana jest przez The History of Cartography, Vol.1, Cartography in Prehistoric, Ancient and Medieval Europe and the Mediterrranean J.B. Harleya i Davida Woodwarda (Chicago-Londyn 1987), History of Cartography Leo Bagrowa i R.A. Skeltona (Cambridge 1966), Vierhundert Jahre Mercator. Vierhundert Jahre Atlas... Eine Geschichte der Atlanten, oprac. Hansa Wolffa (Weisenhorn 1995), Imago Mundi cartographica, Jorg-Geerda Arentzena (Munchen 1984), Katarzyny Zalewskiej-Lorkiewicz, Ilustrowane mappae mundi jako obraz świata (Warszawa 1997).

Publikacje z zakresu historii polskiej kartografi to Karola Buczka Kartografia polska w czasach Stefana Batorego, odbitka z Wiadomości Stużby Geograficznej z 1933 roku, Dzieje kartografii polskiej od XV do XVII wieku (Wrocław 1963), Dziewięć wieków geografii polskiej pod red. B. Olszewicza (Warszawa 1967).

Ciekawymi pozycjami o treści administracyjno-statystycznej są Tabella miast, wsi i osad królestwa Polskiego, z wyrażeniem ich polożenia i ludności alfabetycznie ułożona w Biórze Kommisyi Rząowej Spraw Wewnętrznych Policyi (Warszawa 1827), Antoniego Bobińskiego i Jóżefa Bazewicza 2-tomowy Przewodnik po Królestwie Polskim na podstawie najnowszych źródet opracowany (Warszawa 1901) oraz Skorowidz wszystkich miejscowości położonych w Królestwie Galicji i Lodomeryi... (Lwów 1855).

Interesującymi współcześnie wydawanymi, bogato publikacjami o bogatym materiale ilustracyjnym są katalogi zbiorów i kolekcji. Warto wymienić Wojciecha Kreta Katalog dawnych map Rzeczypospolitej Polskiej w kolekcji Emeryka Hutten Czapskiego i w innych zbiorach (Wrocław 1978-1992) oraz katalogi zbiorów Tomasza Niewodniczańskiego Imago Poloniae i Dantiscum Emporium.

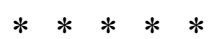

Powyższy krótki opis zasobu zbiorów kartograficznych Biblioteki KUL nie oddaje w pełni jego bogactwa i różnorodności. Sam katalog obejmujący kilka tysięcy dokumentów kartograficznych, zarówno map, jak i atlasów, byłby obszernym wydawnictwem. $Z$ racji tego, że niniejszy artykuł ma ograniczone ramy, nie wyczerpuje z pewnością całości tematu.

Zapewne nie wszyscy czytelnicy Biblioteki Uniwersyteckiej KUL zdają sobie sprawę z tego, jak cenne i rzadkie są przechowywane w niej obiekty pochodzące ze zbiorów kartograficznych. Zarówno dokumenty kartograficzne, jak mapy i atlasy, czy księgozbiór podręczny, służyć mogą jako ciekawy materiał do badań dla naukowców i studentów. Nie tylko geografowie, ale i historycy, czy historycy sztuki mogą znaleźć w nich źródła pomocne w pracy nad swoimi dziedzinami. Także np. badacze dziejów naszego miasta mogą korzystać z wielu planów i prze- 
wodników wydawanych na przestrzeni ostatniego stulecia. Wielka ilość współczesnych map i planów turystycznych może służyć czytelnikom w planowaniu podróży, bądź jako materiał pomocniczy w opracowywaniu prac o szerszym zakresie. Zapewne w dobie Google Earth łatwiej jest w kilka sekund uzyskać na monitorze komputera wszystkie potrzebne informacje, ale nic nie zastapi prawdziwemu koneserowi kontaktu z rzeczywistą mapa, czy atlasem. Opracowanie niniejsze nie jest $\mathrm{w}$ stanie zaprezentować całości zasobu zbiorów kartograficznych, jest raczej próbą zachęcenia przyszłego czytelnika do samodzielnych poszukiwań.

\section{Bibliografia}

Buczek Karol, Dzieje kartografii polskiej od XV do XVIII wieku. Zarys analityczno-syntetyczny. Wrocław 1963.

Centralny Katalog Zbiorów Kartograficznych w Polsce, red. Marian Łodyński, Teresa Paćko, Wojciech Trzebiński, Warszawa 1961-1983.

Eugeniusz Romer, geograf i kartograf trzech epok, katalog wystawy, Warszawa 2004.

Gonczarow Maria, Sekcja Zbiorów Graficznych, Kartograficznych i Nut, „Archiwa Biblioteki i Muzea Kościelne”, 23 (1971).

Grabałowski Ryszard, Imago Mundi, Wrocław 1972.

Hełm-Pirgo Marian, Poczatki kartografii wojskowej w Polsce odrodzonej, New York 1971.

Jodłowski Antoni, Walczy Łukasz, Gawroński Wojciech, Obraz Żupy Wielickiej i miasta Wieliczki na mapach Wilhelma Hondiusa z 1645 roku, Warszawa 2005.

Kartografia Królestwa Polskiego 1815-1915, red. Lucyna Szaniawska i Jerzy Ostrowski, Warszawa 2000.

Nad złoto droższe. Skarby Biblioteki Narodowej, red. H. Tchórzewska-Kabaty, Warszawa 2000.

Olszewicz Bolesław, Kartografia polska XV-XVII wieku. Przeglad chronologiczno-bibliograficzny, Warszawa 2004.

Olszewicz Bolesław, Kartografia polska XIX wieku. Przeglad chronologicznobibliograficzny, Warszawa 1998.

Olszewicz Bolesław, Polska kartografja wojskowa, Warszawa 1921.

Rastawiecki Edward, Mappografia dawnej Polski, Warszawa 1846.

Rzepa Zbigniew, Kartografia historyczna Joachima Lelewela, Ze skarbca kultury, z. 34, 1980.

Sirko Mieczysław, Zarys historii kartografii, Lublin 1999.

Szady Bogumił, Mapa unickiej diecezji chetmskiej z 1782 roku jako przyktad kartografii wyznaniowej, rkps udostępniony przez autora.

Szaflarski Józef, Zarys kartografii, Warszawa 1955.

Szykuła Krystyna, Zbiory kartograficzne Biblioteki Uniwersyteckiej we Wroctawiu, Wrocław 1978. 
Vierhundert Jahre Mercator. Vierhundert Jahre Atlas... Eine Geschichte der Atlanten, oprac. Hans Wolff, Weisenhorn 1995.

Winiarczyk Barbara, Zbiory kartograficzne, W: Zbiory specjalne Biblioteki Uniwersyteckiej Katolickiego Uniwersytetu Lubelskiego, red. Małgorzata Trojnacka, Lublin 2004.

Wśród starych map i atlasów Biblioteki Narodowej w Warszawie, red. B. Krassowski, Warszawa 1982.

Zarys organizacji, rozwoju i działalności Wojskowego Instytutu Geograficznego, Warszawa 1924.

\section{DIE KARTOGRAPHISCHEN SAMMLUNGEN DER UNIVERSITÄTSBIBLIOTHEK DER KUL}

\section{Zusammenfassung}

Kartographische Dokumente wurden in der Universitätsbibliothek der Katholischen Universität Lublin von Anfang ihres Bestehens an gesammelt, d.h. seit 1918, und mit ihrer systematischen Bearbeitung begann man 1948. Die Sektion Graphische, Kartographische und Musikalische Sammlungen, die im Rahmen der Abteilung Spezialsammlungen funktioniert, ist gegenwärtig im Besitz von 1300 Atlanten, beinahe 900 Karten, fast 3000 Leitfäden bzw. Reiseführern sowie ungefähr 300 Volumina in der Handbibliothek.

Die Sammlung der ältesten und wertvollsten Atlanten und Karten mit Denkmalswert enthält Werke der hervorragendsten europäischen Kartographen - von Abraham Ortelius (u.a. „Theatrum Orbis Terarum”), Gerhard Kremer, genannt Mercator („Atlas sive cosmographicae" und „Atlas minor"), John Speed, Johann Baptist Homann, Giovanni RizziZannoni und vielen anderen. Die polnischen Autoren des 19. Jahrhunderts sind u.a. durch Stanisław Staszic, Joachim Lelewel, Juliusz Kolberg und Wojciech Chrzanowski vertreten. Von den polnischen kartographischen Verlagserzeugnissen des 20. Jahrhunderts müssen erwähnt werden die Veröffentlichungen aus Warschau (die vorzüglichen WIG-Karten) und Lwów/Lemberg (die Karten und Atlanten der „Książnica” sowie der Atlas von Eugeniusz Romer).

Unter den Karten finden sich mehrere Unikate - der „Plan der Grube und der Stadt Wieliczka” von Marcin German und Wilhelm Hondius, die handschriftliche „Mappa dioeceseos Chelmensis et Belzensis...” sowie „Magnis Ducatus Lithuaniae” von Tomasz Makowski (die sogenannte Radziwiłł-Karte).

Die Sammlung touristischer Reiseführer umfasst viele polnische und ausländische Publikationen, auch aus der Vorkriegszeit. Hier findet man Reiseführer aus den sogenannten Ostgebieten, eine Sammlung von Friedhofsführern sowie die heute herausgegebenen Reihen von „National Geographic” oder vom Verlag „Pascal”.

Die kartographische Handbibliothek enthält grundlegende Publikationen, die als Hilfsmittel zur Bearbeitung kartographischer Dokumente dienen. Außer Bibliographien, gedruckten Katalogen und Wörterbüchern findet man dort auch Werke aus dem Bereich der Geschichte und Theorie der Kartographie. $\mathrm{Zu}$ den wertvollsten Titeln gehören der 
„Katalog der Atlanten aus der Bibliothek der Stefan-Batory-Universität in Wilna” von Mikołaj Dzikowski sowie „Kartographie des früheren Polen” von Edward Rastawiecki.

Die kartographischen Sammlungen der Universitätsbibliothek der KUL bilden eine hervorragende Quelle des Wissens für Geographen, Historiker und Kunsthistoriker. Da sich nicht alle Leser der Bibliothek über die reiche Fülle der dort aufbewahrten Sammlungen bewusst sind, stellt der vorliegende Beitrag den Versuch einer Gesamtschau der kartographischen Bestände dar und soll zur selbständigen Suche ermuntern.

Aus dem Polnischen übersetzt von Herbert Ulrich 